\title{
FASILITAS SANITASI PADA WISATA RELIGI SUNAN AMPEL SURABAYA TAHUN 2016
}

\author{
Ennovika Egatha Mareta, Bambang Sunarko, Suprijandani
}

\begin{abstract}
Tourism is a gathering place for a lot of people both adults and children so that it potential both as the site of disease transmission, environmental pollution, or other health problems. Therefore, the facilities provided must be complete, so that surveillance and inspection of sanitation in public places is very necessary to prevent transmission of disease and other health problems as well.

This research was descriptive, which will describe about the state of sanitation facilities in SunanAmpel Religious Tourism of Surabaya Year 2016. Data collection was conducted by interviewing the manager and observation by using the tourism object appraisal form.

Based on the results of observation at the sites, the object was concidered fair in category (69.7\%). This case due to the state of the environment also in fair category (73\%), the state of sanitation facilities was fair category (77\%), state of the supporting facilities down to poor category (35\%), the state of mosque sanitation included in the good category (82\%).

Final result of study concluded that the state of Sunan Ampel Religious Tourism of Surabaya was in the category of Fair (69.7\%); it is suggested to the manager of the Sunan Ampel Religious Tourism of Surabaya to continuously monitor and keeping clean the environment of mosque area, grave, and the cleanliness of toilets. The trash place should be replaced using the garbage bins which are not easily corroded and fitted with a lid, janitors expected to make a schedule of transporting waste to landfill in maximum of every 3 days and move poolling locations to other empty sites. In the tourism object it's suggested to provide health tools/facilities, with the availability of First Aid box.
\end{abstract}

\section{Keywords $\quad$ : Sanitation Facilities, Sunan Ampel Religious Tourism of Surabaya}

\section{PENDAHULUAN}

Tempat-tempat umum memiliki potensi sebagai tempat terjadinya penularan penyakit, pencemaran lingkungan, ataupun gangguan kesehatan lainnya. Pengawasan, pemeriksaan, dan pemeliharaan fasilitas sanitasi terhadap tempat-tempat umum dilakukan untuk mewujudkan lingkungan tempat-tempat umum yang bersih guna melindungi kesehatan masyarakat dari kemungkinan penularan penyakit dan gangguan kesehatan lainnya. Tempat atau sarana layanan umum yang wajib menyelenggarakan sanitasi lingkungan adalah tempat umum yang dikelola secara komersial, tempat yang memfasilitasi terjadinya penularan penyakit, atau tempat layanan umum yang intensitas jumlah dan waktu kunjungannya tinggi. (Chandra, 2007)

Wisata Religi Sunan Ampel Surabaya sering dikunjungi oleh para wisatawan, tempat ini terbuka 24 jam dan menjadi daya tarik tersendiri bagi masyarakat muslim untuk berziarah ke makam Sunan Ampel. Pengunjung yang datang ada yang perorangan dan rombongan. Pengunjung tidak hanya berasal dari masyarakat Surabaya saja melainkan dari luar kota maupun luar negeri. Banyaknya jumlah pengunjung dan kurangnya pemeliharaan fasilitas sanitasi membuat tingginya peluang terjadinya penularan penyakit. Penyakit yang menyerang dapat ditularkan dan menyebar secara langsung maupun tidak langsung melalui kualitas dan kuantitas air, tempat sampah, dan toilet.Oleh karena itu pemeliharaan fasilitas sanitasi Wisata Religi Sunan Ampel Surabaya harus terjaga dan terinspeksi dengan baik.

Hasil survey awal di Wisata Religi Sunan Ampel Surabaya pada bulan Desember 2015 dan juga wawancara dengan ketua pengelola Wisata Religi Sunan Ampel Surabaya diketahui bahwa toilet yang ada di Wisata Religi Sunan Ampel Surabaya kurang mencukupi, untuk 2000 pengunjung pada hari biasa dan sekitar 3000 pengunjung pada hari libur hanya tersedia 20 buah jamban untuk pria dan 20 buah jamban untuk wanita.

Sarana penyediaan air bersih yang digunakan untuk memenuhi kebutuhan di Wisata Religi Sunan Ampel seperti wudhu, Buang Air Besar (BAB), mandi dan lain-lain berasal dari air sumur. Sarana pembuangan air limbah seperti limbah kamar mandi dan limbah Water Closed (WC) dibuang ke saluran tersendiri sedangkan limbah air hujan disalurkan atau dibuang ke badan air. Kondisi halaman masjid dan halaman makam masih terdapat sampah yang berserakan seperti bungkus plastik, botol, bekas rokok dan daun-daun hal tersebut mengurangi keindahan area halaman wisata religi. Penelitian ini bertujuan untuk mengetahui keadaan fasilitas sanitasi pada Wisata Religi Sunan Ampel Surabaya tahun 2016. 


\section{METODE PENELITIAN}

Penelitian ini menggunakan metode deskriptif, yaitu penelitian yang digunakan untuk mendeskripsikan atau menggambarkan suatu fenomena yang terjadi di dalam masyarakat (Notoatmodjo, 2010). Pada penelitian ini akan dideskripsikan keadaan fasilitas sanitasi di Wisata Religi Sunan Ampel Surabaya pada tahun 2016.

Data yang diperoleh langsung oleh peneliti melalui kegiatan wawancara, observasi, tanya jawab (checklist), pengukuran kualitas dan kuantitas air bersih. Data yang telah tersedia di lapangan yang dikumpulkan oleh pihak lain kemudian dikumpulkan oleh peneliti melalui penelusuran dokumen di tempat penelitian. Data sekunder terdiri dari jumlah pengunjung, luas area dan denah lokasi Wisata Religi Sunan Ampel Surabaya.

\section{HASIL PENELITIAN DAN PEMBAHASAN}

Penelitian dilakukan pada bulan Januari 2016 dengan cara observasi di lokasi Wisata Religi Sunan Ampel Surabaya. Penilaian menggunakan formulir penilaian (checklist), mengukur dan memeriksa semua sasaran penelitian serta melakukan tanya jawab dengan pengelola obyek wisata tersebut.

1. Keadaan Lingkungan di Wisata Religi Sunan Ampel Surabaya

Berdasarkan hasil penilaian kesehatan lingkungan di Wisata Religi Sunan Ampel Surabaya tahun 2016 termasuk dalam kategori Cukup (73\%). Hal ini dikarenakan halaman tempat ziarah dan halaman sekitar masjid kurang bersih, masih banyak sampah berserakan seperti bungkus plastik, botol, bekas rokok dan daun-daun.Hal tersebut tidak sesuai Menurut Suparlan (2012) kondisi lingkungan harus memenuhi dua aspek, yaitu bersih dan sehat. Bersih dalam arti tersedia tempat sampah minimal 1 buah dalam radius setiap 10 meter, sampah tidak berserakan, dan drainase selokan dalam keadaan bersih.

Kondisi yang kurang bersih dapat menjadi sumber penyakit karena menurut Imran (2005) sampah merupakan sumber penyakit, baik secara langsung maupun tidak langsung. Secara langsung sampah merupakan tempat berkembangnya berbagai parasit, bakteri dan patogen; sedangkan secara tak langsung sampah merupakan sarang berbagai vektor (pembawa penyakit) seperti tikus, kecoa, lalat dan nyamuk. Sampah yang membusuk; maupun kaleng, botol, plastik; merupakan sarang patogen dan vektor penyakit. Berbagai penyakit yang dapat muncul karena sampah yang tidak dikelola antara lain adalah, diare, disentri, cacingan, malaria, kaki gajah dan demam berdarah. Penyakit-penyakit ini merupakan ancaman bagi manusia, yang dapat menimbulkan kematian. Sampah yang tidak dikelola dengan baik akan menjadi penyebab gangguan dan ketidak seimbangan lingkungan, selain itu sampah padat yang menumpuk ataupun yang berserakan menimbulkan kesan kotor dan kumuh. sehingga nilai estetika pemukiman dan kawasan disekitar sampah terlihat sangat rendah.

Sistem drainase di Wisata Religi Sunan Ampel Surabaya berfungsi dengan baik, sehingga dilokasi tersebut tidak ada genangan air. Pembuangan air limbah seperti limbah kamar mandi dan limbah WC dibuang ke saluran tersendiri sedangkan limbah air hujan disalurkan atau dibuang ke badan air. Pembuangan air limbah memenuhi syarat karena saluran pembuangan limbah tertutup, tidak terjadi kebocoran dan pembuangan tinja dilakukan oleh pihak ketiga.Hal tersebut sesuai Menurut Al Amin (2009) Sistem drainase yang baik harus dapat menampung pembuangan air semaksimal mungkin, sehingga apabila debit air lebih dari yang diperkirakan, sistem drainase tersebut masih dapat menampung dan mengalirkannya sehingga tidak terjadi genangan air pada saat hujan turun di kawasan tersebut.

2. Keadaan Fasilitas Sanitasi

Dari hasil observasi mengenai keadaan fasilitas sanitasi yang meliputi air bersih, toilet umum, pembuangan air limbah dan tempat sampah, diperoleh hasil observasi yang ditunjukkan pada tabel 1 berikut:

Tabel 1

Hasil Penilaian Keadaan Fasilitas Sanitasi Di Wisata Religi Sunan Ampel Surabaya Tahun 2016

\begin{tabular}{clcccc}
\hline No & \multicolumn{1}{c}{ Variabel } & Skor Maks & $\begin{array}{c}\text { Skor } \\
\text { Obs. }\end{array}$ & $(\%)$ & Kriteria \\
\hline 1. & Air Bersih & 160 & 160 & 100 & Baik \\
\hline 2. & Toilet Umum & 160 & 110 & 68 & Cukup \\
\hline 3. & Pembuangan Air Limbah & 140 & 140 & 100 & Baik \\
\hline 4. & Tempat Sampah & 140 & 55 & 39 & Kurang \\
\hline & Jumlah & 600 & 465 & 77 & Cukup
\end{tabular}

Sumber: Data Primer 
Berdasarkan hasil penilaian tentang fasilitas sanitasi di Wisata Religi Sunan Ampel Surabaya pada Tabel 1 memperoleh hasil $465(77 \%)$ dari jumlah skor maksimal 600 (100\%) dengan kriteria cukup.

a. Air Bersih

Berdasarkan hasil penilaian fasilitas penyediaan air bersih di Wisata Religi Sunan Ampel Surabaya tahun 2016 termasuk dalam kategori Baik (100\%) seperti terlihat pada tabel 1 .

Air bersih yang ada dilokasi tersebut berasal dari sumur gali yang dipompa kemudian ditampung pada tandon air yang ada diatas kamar mandi, kemudian air didistribusikan menuju kamar mandi dan kran-kran di tempat wudhu.

Dari hasil pemeriksaan fisik, bakteriologis dan kimia air bersih di lokasi tersebut memperoleh kriteria memenuhi syarat. Telah diperoleh hasil pemeriksaan fisik air tersebut tidak berbau, tidak berwarna dan tidak berasa. Pada pemeriksaan bakteriologis terdiri dari MPN dengan hasil 23 koloni/100ml dan negatif E.Coli. Parameter kimia yang diperiksa adalah derajat keasaman $(\mathrm{pH})$ diperoleh hasil 7,0 dengan standar 6,59,2 . Hal tersebut sesuai dengan Permenkes No. 416 Tahun 1990 tentang syarat-syarat dan pengawasan kualitas air yaitu syarat fisik tidak berbau, tidak berwarna dan tidak berasa. Syarat bakteriologis yaitu bakteri yang tidak berbahaya namun menjadi indikator pencemaran tinja (Coliform bacteria) harus negatif dan dalam $100 \mathrm{ml}$ air jumlah MPN Coliform tidak boleh lebih dari 50 coloni (air bersih bukan perpipaan).

Dari segi kuantitas dan sarana penyimpanan dilokasi tersebut air selalu mengalir lancar, bak penyimpanan air selalu terisi penuh, penyimpanan air bersih terbuat dari bahan yang kuat, kedap air, bersih, dan mudah dibersihkan. Kuantitas air diukur dengan pengukuran debit air diperoleh hasil 22.118 liter/detik/hari sehingga hasil tersebut sesuai dengan Kriteria Perencanaan Ditjen Cipta Karya Dinas PU (2000) kebutuhan air bersih pada tempat pariwisata yaitu 0,1-0,3 liter/detik/hari. Berikutinipengukuran debit air bersih di Wisata Religi Sunan Ampel Surabaya :

$\mathrm{Q}$ : Debit V: Volume t : Waktu

$$
\begin{aligned}
& \mathrm{Q}=\mathrm{V} / \mathrm{t} \\
& \mathrm{Q}=1280 \mathrm{ml} / 5 \mathrm{dt} \\
& =256 \mathrm{ml} \\
& =0,256 \mathrm{lt} / \mathrm{dt} \\
& =22.118 \mathrm{lt} / \text { detik/hari }
\end{aligned}
$$

b. Toilet Umum

Berdasarkanhasilpenilaianfasilitas

toilet umum di Wisata Religi Sunan Ampel Surabaya tahun 2016 termasuk dalam kategori Cukup (68\%) seperti terlihat pada tabel 1

Toilet umum dilokasi tersebut dipisahkan antara toilet laki-laki dan perempuan. Kondisi toilet dilokasi tersebut masih terlihat kotor terutama kondisi toilet pria kurang terpelihara karena kurang bersih dan bau. Dari segi konstruksi lantai rata tetapi kurang bersih karena adanya lumut di lantai permukaannya licin sehingga berpotensi menyebabkan kecelakaan seperti terpeleset.Kondisi dinding rata, kuat, dan kedap air.Jamban menggunakan tipe leher angsa dilengkapi dengan septic tank.Tersedia tempat sampah tetapi tidak bertutup.Jumlah toilet yang ada di lokasi tersebut kurang mencukupi sehingga banyak yang mengantri, untuk 2000 pengunjung pada hari biasa dan sekitar >3000 pengunjung pada hari libur hanya tersedia 20 buah jamban untuk pria dan 20 buah jamban untuk wanita. Sehingga jumlah jamban di Wisata Religi Sunan Ampel Surabaya belum memenuhi syarat.

Hal tersebut tidak sesuai Menurut Azwar dalam buku "Pengantar Ilmu Kesehatan Lingkungan" (1995), bahwa syarat pembuangan kotoran manusia (toilet) :

1) Dalam keadaan bersih dan tidak berbau

2) Lantai kedap air,permukaanya rata,tidak licin,mudah dibersihkan dan mempunyai kemiringan 1-3\% kearah saluran pembuangan

3) Menggunakan jamban tipe leher angsa yang dilengkapi dengan septic tank

4) Tidak menjadi tempat bersarangnya serangga dan vektor pengganggu

5) Dilengkapi dengan ventilasi yang cukup minimal $10 \%$ dari lantai

6) Tersedia lampu penerangan yang cukup

7) Disediakan jamban untuk 60 pengunjung pria dan 1 jamban bagi 40 pengunjung wanita.

c. Pembuangan Air Limbah Berdasarkanhasilpenilaianfasilitas Pembuangan Air Limbah di Wisata Religi Sunan Ampel Surabaya tahun 2016 termasuk dalam kategori Baik (100\%) seperti terlihat pada tabel 1

Pembuangan air limbah di lokasi Wisata Religi Sunan Ampel Surabaya seperti limbah kamar mandi dan limbah 
WC dibuang ke saluran tersendiri, pembuangan tinja dilakukan oleh pihak ketiga sedangkan limbah air hujan disalurkan atau dibuang ke badan air. Pembuangan air limbah memenuhi syarat karena saluran pembuangan limbah tertutup sehingga tidak dihinggapi oleh serangga, tikus, dan tidak menjadi tempat berkembang biaknya berbagai bibit penyakit dan vektor serta baunya tidak mengganggu, tidak adanya sampah yang menyumbat sehingga limbah mengalir lancar. Dari segi konstruksi, saluran pembuangan air limbah kuat, kedap air dan tidak terjadi kebocoran. Hal tersebut sesuai Menurut Suparlan (2012), bahwa sistem pengolahan air limbah yang diharapkan harus memenuhi persyaratan yaitu Syarat sarana pembuangan air limbah :

1) Tidak mencemari tanah

2) Tidak mencemari air permukaan

3) Saluran menggunakan system tertutup, kedap air

4) Air limbah yang dibuang harus dapat mengalir dengan lancar

5) Tidak menimbulkan bau

6) Tidak menjadi sumber penularan penyakit

d. Tempat Sampah

Berdasarkan hasil penilaian fasilitas Tempat Sampah di Wisata Religi Sunan Ampel Surabaya tahun 2016 termasuk dalam kategori Kurang (39\%) seperti

Jumlah tempat sampah dilokasi tersebut memenuhi syarat, pada radius setiap <20 meter tersedia satu tempat sampah. Kualitas tempat sampah yang ada dilokasi tersebut tidak memenuhi syarat dikarenakan tempat sampah terbuat dari besi yang mudah berkarat dan tempat sampah yang terbuat dari plastik tidak mempunyai tutup. Hal ini dapat berpotensi mengundang banyak binatang pengganggu seperti lalat dan tikus. Terlebih pada hari libur atau harihari besar jumlah pengunjung meningkat tajam karena setiap hari lokasi itu buka 24jam yang mengakibatkan jumlah timbunan sampah juga bertambah, jika tidak ditutup maka menimbulkan bau dan akan mengurangi nilai estetika sehingga terlihat pada tabel 1

dapat mengganggu kenyamanan pengunjung.

Hal tersebut tidak sesuai Menurut Notoatmodjo (2011) syarat tempat sampah yang baik antara lain : konstruksinya kuat agar tidak mudah bocor, memiliki tutup dan mudah dibuka tanpa mengotori tangan, ukuran sesuai sehingga mudah diangkut oleh satu orang, dan mudah dibersihkan. Pemusnahan sampah dilakukan dengan ditanam, dibakar, dijadikan pupuk, dan didaur ulang.

Penanganan sampah di Wisata Religi Sunan Ampel Surabaya adalah dengan menampung sampah pada tiap-tiap tempat sampah, sampah akan diangkut dengan gerobak sampah kemudian ditampung pada tempat pembuangan sampah sementara (TPS) yang berada dibelakang dekat dengan tempat parkir mobil. Sampah dikumpulkan di TPS yang tidak tertutup dan sampah diangkut ke TPA Benowo 5 hari sekali.

$\mathrm{Hal}$ tersebut tidak sesuai menurut Sarudji (2006), bahwa syarat Pembuangan Tempat Sampah meliputi tempat penampungan sampah sementara harus terletak pada tempat yang strategis. Kontainer terbuat dari bahan yang kuat, kedap air, tidak permanen, dan terdapat tutup / tertutup. Tempat penampungan sampah sementara mudah dijangkau oleh kendaraan pengangkut sampah dan frekuensi pengosongan atau pengangkutan sampah minimal $3 \times 24$ jam.

Maka dari itu, pihak pengelola diharapkan untuk membuat jadwal pengangkutan sampah ke TPA maksima 3 hari sekali dan memindahkan lokasi TPS ke lokasi yang tidak banyak dilewati dan didatangi oleh pengunjung sehingga tidak mengganggu estetika dan lalu lintas.

3. Keadaan Fasilitas Penunjang

Dari hasil observasi mengenai keadaan fasilitas lain-lain yang meliputi sarana penyuluhan, sarana/fasilitas kesehatan, alat pemadam kebakaran, dan sanitasi masjid, diperoleh hasil observasi yang ditunjukkan pada tabel 2 berikut:

Tabel 2

Hasil Penilaian Keadaan Fasilitas Penunjang di Wisata Religi Sunan Ampel Surabaya Tahun 2016

\begin{tabular}{cccccc}
\hline No & Variabel & Skor Maks & Skor Obs. & $(\%)$ & Kriteria \\
\hline 1. & Sarana Penyuluhan & 80 & 20 & 25 & Kurang \\
\hline 2. & Sarana/fasilitas kesehatan & 60 & 2 & 3 & Kurang \\
\hline 3. & Alat Pemadam Kebakaran & 50 & 45 & 90 & Baik \\
\hline & Jumlah & 190 & 67 & 35 & Kurang \\
\hline
\end{tabular}


Sumber: Data Primer

Berdasarkan hasil penilaian tentang fasilitas penunjang di Wisata Religi Sunan Ampel Surabaya pada Tabel 2 memperoleh hasil 67 (35\%) dari jumlah skor maksimal 190 (100\%) dengan kriteria kurang.

\section{Sarana penyuluhan}

Berdasarkan hasil penilaian sarana penyuluhan di Wisata Religi Sunan Ampel Surabaya tahun 2016 termasuk dalam kategori Kurang (25\%) seperti terlihat pada tabel 2. Untuk sarana penyuluhan di lokasi tersebut menggunakan papan peringatan "Jagalah Kebersihan" yang ada di dinding. Jadi, sarana penyuluhan dilokasi tersebut tidak menggunakan alat pengeras suara hanya menggunakan papan peringatan yang ada di dinding saja.

Hal tersebut sesuai Menurut Suparlan (2012) dalam buku yang berjudul Pengantar Pengawasan Hygiene Sanitasi Tempat-Tempat Umum Wisata dan Usaha-Usaha untuk Umum, menjelaskan bahwa salah satu persyaratan untuk kebersihan dan kesehatan obyek wisata adalah perlu ditambahkan tanda-tanda peringatan/petunjuk seperti petunjuk menjaga kebersihan dan keamanan. Sarana penyuluhan terdapat dua cara, yaitu penyuluhan secara langsung dan tidak langsung. Penyuluhan secara langsung dilakukan melalui alat pengeras suara. Penyuluhan secara tidak langsung dilakukan melalui media cetak seperti leaflet, poster, flip chart, dll.

\section{Sarana/fasilitas Kesehatan}

Berdasarkan hasil penilaian sarana/fasilitas kesehatan di Wisata Religi Sunan Ampel Surabaya tahun 2016 termasuk dalam kategori Kurang (3\%) seperti terlihat pada tabel 2. Hasil observasi di lokasi tersebut tidak tersedia poliklinik/balai pengobatan dan tidak tersedia kotak P3K sehingga jika tidak ada fasilitas tersebut, maka saat ada korban kecelakaan atau penderita akan menjadi lebih parah jika tidak segera mendapatkan pertolongan pertama. Hal tersebut tidak sesuai menurut Yoeti (2006) Harus ada poliklinik poli umum/jaminan ketersediaan pelayanan yang baik untuk penyakit yang mungkin diderita wisatawan.

\section{Alat Pemadam Kebakaran}

Berdasarkan hasil penilaian Alat Pemadam Kebakaran di Wisata Religi Sunan Ampel Surabaya tahun 2016 termasuk dalam kategori Baik (90\%) seperti terlihat pada tabel 2

Dilokasi tersebut tersedia alat pemadam kebakaran yang berfungsi dengan baik terletak diruang kantor informasi dan terdapat penjelasan tentang cara penggunaannya, sehingga jika terjadi kebakaran dapat mencegahpengunjung dari kejadian kecelakaan akibat menggunakan fasilitas tempat-tempat umum.

Hal tersebut sesuai Menurut Suyono (2010) bahwa salah satu syarat pencegahan kecelakaan adalah tersedia alat pemadam kebakaran tabung maupun otomatik sprinker, pencegahan kecelakaan tersebut digunakan untuk menjamin pengunjung dari kejadian kecelakaan akibat menggunakan fasilitas tempat-tempat umum.

\section{Sanitasi Masjid}

Dari hasil observasi mengenai keadaan sanitasi Masjid Ampel Surabaya meliputi variabel letak, konstruksi, dan beberapa persyaratan yang ditunjukkan pada tabel 3 berikut :

Tabel 3

Hasil Penilaian Keadaan Sanitasi Masjid Di Wisata Religi Sunan Ampel Surabaya Tahun 2016

\begin{tabular}{clcccc}
\hline No & Variabel & Skor Maks & Skor Obs. & $(\%)$ & Kriteria \\
\hline 1. & Letak & 20 & 20 & 100 & Baik \\
\hline 2. & Konstruksi & 15 & 15 & 100 & Baik \\
\hline 3. & Halaman & 10 & 5 & 50 & Kurang \\
\hline 4. & Tempat Sampah & 10 & 5 & 50 & Kurang \\
\hline 5. & Pembuangan air & 5 & 5 & 100 & Baik \\
\hline 6. & Persediaan air & 10 & 10 & 100 & Baik \\
\hline 7. & Toilet/Jamban & 5 & 3 & 60 & Cukup \\
\hline
\end{tabular}




\begin{tabular}{clcccc}
\hline 8. & Tempat Wudhu & 5 & 5 & 100 & Baik \\
\hline 9. & Alat sholat & 10 & 8 & 80 & Baik \\
\hline 10. & Lantai & 10 & 10 & 100 & Baik \\
\hline 11. & Ventilasi & 10 & 10 & 100 & Baik \\
\hline 12. & Pencahayaan & 10 & 10 & 100 & Baik \\
\hline 13. & Tempat sandal & 10 & 1 & 10 & Kurang \\
\hline & Jumlah & 130 & 107 & 82 & Baik \\
\hline
\end{tabular}

Berdasarkan hasil penilaian tentang fasilitas penunjang di Wisata Religi Sunan Ampel Surabaya pada Tabel 3 memperoleh hasil 107 (82\%) dari jumlah skor maksimal 130 $(100 \%)$ dengan kriteria baik.

a. Letak

Berdasarkan hasil penilaian mengenai keadaan letak masjid di Wisata Religi Sunan Ampel Surabaya tahun 2016 termasuk dalam kategori Baik (100\%) seperti terlihat pada tabel 3. Berdasarkan hasil wawancara kepada ketua pengelola bahwa letak Masjid Ampel telah sesuai dengan rencana tata kota karena program bangunan dan lingkungan masjid dilakukan melalui analisis kawasan dan wilayah perencanaan kota.Hal tersebut sesuai menurut Permen-PU No. 06/PRT/M/2007 tentangPedoman Umum Rencana Tata Bangunan dan Lingkungan bahwa program bangunan dan lingkungan dilakukan melalui analisis kawasan dan wilayah perencanaan kota termasuk mengenai pengendalian dampak lingkungan, dan analisis pengembangan pembangunan berbasis peran masyarakat, yang menghasilkan konsep dasar perancangan tata bangunan dan lingkungan.

b. Konstruksi

Berdasarkan hasil penilaian mengenai keadaan konstruksi masjid di Wisata Religi Sunan Ampel Surabaya tahun 2016 termasuk dalam kategori Baik $(100 \%)$ seperti terlihat pada tabel 3 Berdasarkan observasi konstruksi masjid ampel kuat dan aman diliat dari tiang masjid dan atap nya kuat.Menurut Anom (1999) Masjid Ampel ini juga dipercaya memiliki karomah atau kemuliaan tersendiri karena meski diserang penjajah berkali-kali namun tidak mengalami kerusakan, kayu-kayu jatinya tetap berdiri dengan kokoh menopang masjid.

c. Halaman

Berdasarkan hasil penilaian mengenai keadaan halaman masjid di Wisata Religi Sunan Ampel Surabaya tahun 2016 termasuk dalam kategori Kurang(50\%) sepertiterlihatpadatabel IV.3. Halaman masjid kurang bersih karena masih banyak sampah yang berserakan disebabkan oleh banyaknya pengunjung yang membuang sampah sembarangan dan kurangnya pengawasan dari petugas kebersihan.Tidak ada genangan air disekitar halaman masjid karena sistem drainase dilokasi tersebut berfungsi dengan baik. Hal tersebut tidak sesuai Menurut Suparlan (2012) kondisi lingkungan harus memenuhi dua aspek, yaitu bersih dan sehat.

d. Tempat Sampah

Berdasarkan hasil penilaian mengenai keadaan tempat sampah di Masjid Ampel tahun 2016 termasuk dalam kategori Kurang (50\%) seperti terlihat pada tabel 3. Di Masjid Ampel tersedia satu tempat sampah pada radius setiap <20 meter.Kualitas tempat sampah yang ada dilokasi tersebut tidak memenuhi syarat dikarenakan tempat sampah terbuat dari besi yang mudah berkarat dan tempat sampah yang terbuat dari plastik tidak mempunyai tutup.Hal ini dapat berpotensi mengundang banyak binatang pengganggu seperti lalat dan tikus. Terlebih pada hari libur atau hari-hari besar jumlah pengunjung meningkat tajam karena setiap hari lokasi itu buka 24jam yang mengakibatkan jumlah timbunan sampah juga bertambah, jika tidak ditutup maka menimbulkan bau dan akan mengurangi nilai estetika sehingga dapat mengganggu kenyamanan pengunjung. $\mathrm{Hal}$ tersebut tidak sesuai Menurut 
Notoatmodjo (2011) syarat tempat sampah yang baik antara lain : konstruksinya kuat agar tidak mudah bocor, memiliki tutup dan mudah dibuka tanpa mengotori tangan, ukuran sesuai sehingga mudah diangkut oleh satu orang, dan mudah dibersihkan. Pemusnahan sampah dilakukan dengan ditanam, dibakar, dijadikan pupuk, dan didaur ulang.

e. Pembuangan Air Limbah

Berdasarkan hasil penilaian mengenai keadaan pembuangan air limbah di Masjid Ampel tahun 2016 termasuk dalam kategori Baik (100\%) seperti terlihat pada tabel 3. Pembuangan air limbah di Masjid Ampel seperti limbah kamar mandi dan limbah WC dibuang ke saluran tersendiri, pembuangan tinja dilakukan oleh pihak ketiga sedangkan limbah air hujan disalurkan atau dibuang ke badan air. Pembuangan air limbah memenuhi syarat karena saluran pembuangan limbah tertutup sehingga tidak dihinggapi oleh serangga, tikus, dan tidak menjadi tempat berkembang biaknya berbagai bibit penyakit dan vektor serta baunya tidak mengganggu, tidak adanya sampah yang menyumbat sehingga limbah mengalir lancar. Dari segi konstruksi, saluran pembuangan air limbah kuat, kedap air dan tidak terjadi kebocoran.

f. Persediaan Air Bersih

Berdasarkan hasil penilaian mengenai keadaan persediaan air bersih di Masjid Ampel tahun 2016 termasuk dalam kategori Baik (100\%) seperti terlihat pada tabel 3. Air bersih yang ada dilokasi tersebut berasal dari sumur gali yang dipompa kemudian ditampung pada tandon air yang ada diatas kamar mandi, kemudian air didistribusikan menuju kamar mandi dan kran-kran di tempat wudhu. Dari hasilpemeriksaanfisik, bakteriologis dan kimia air bersih di lokasi tersebut memperoleh kriteria memenuhi syarat.Telah diperoleh hasil pemeriksaan fisik air tersebut tidak berbau, tidak berwarna dan tidak berasa.Pada pemeriksaan bakteriologis terdiri dari MPN dengan hasil 23 koloni/100ml dan negatif E.Coli.Parameter kimia yang diperiksa adalah derajat keasaman $(\mathrm{pH})$ diperoleh hasil 7,0 dengan standar 6,59,2. Hal tersebut sesuai dengan Permenkes No. 416 Tahun 1990 tentang syarat-syarat dan pengawasan kualitas air yaitu syarat fisik tidak berbau, tidak berwarna dan tidak berasa. Syarat bakteriologis yaitu bakteri yang tidak berbahaya namun menjadi indikator pencemaran tinja (Coliform bacteria) harus negatif dan dalam $100 \mathrm{ml}$ air jumlah MPN Coliform tidak boleh lebih dari 50 coloni (air bersihbukanperpipaan).

g. Toilet/Jamban

Berdasarkan hasil penilaian mengenai keadaan toilet/jamban di Masjid Ampel

tahun 2016 termasuk dalam kategori Cukup (60\%) seperti terlihat pada tabel 3. Toilet umum di Masjid Ampel tersebut dipisahkan antara toilet lakilaki dan perempuan. Kondisi toilet dilokasi tersebut masih terlihat kotor terutama kondisi toilet pria kurang terpelihara karena kurang bersih dan bau. Dari segi konstruksi lantai rata tetapi kurang bersih karena adanya lumut di lantai permukaannya licin sehingga berpotensi menyebabkan kecelakaan seperti terpeleset.Kondisi dinding rata, kuat, dan kedap air.Jamban menggunakan tipe leher angsa dilengkapi dengan septic tank.Tersedia tempat sampah tetapi tidak bertutup.Jumlah toilet yang ada di lokasi tersebut kurang mencukupi sehingga banyak yang mengantri, untuk 2000 pengunjung pada hari biasa dan sekitar $>3000$ pengunjung pada hari libur hanya tersedia 20 buah jamban untuk pria dan 20 buah jamban untuk wanita. Sehingga jumlah jamban di Wisata Religi Sunan Ampel Surabaya belum memenuhi syarat.

h. Tempat Wudhu

Berdasarkan hasil penilaian mengenai keadaan tempat wudhu di Masjid Ampel tahun 2016 termasuk dalam kategori Baik (100\%) seperti terlihat pada tabel 3. Ruangtempat air wudhu di Masjid Ampel terpisah dari jamban dan ruang masjid. Hal tersebut sesuai menurut Keputusan Menteri Kesehatan RI Nomor: 288/Menkes/SK/III/2003 tentang "Pedoman Penyehatan Sarana dan Bangunan Umum Masjid, Langgar, dan Surau" bahwa ruang tempat mengambil air wudlu harus terpisah dari jambandanruangan masjid.

i. Alat sholat

Berdasarkan hasil penilaian mengenai keadaan alat sholat di Masjid Ampel tahun 2016 termasuk dalam kategori Baik(100\%) seperti terlihat pada tabel 3. Peralatan sholat di Masjid Ampel 
cukup memadai, tersedia tempat penyimpanan peralatan ibadah yang disusun secara rapi, serta dilakukan pencucian setiap 1-2 minggu sekali, sehingga peralatan sholat dalam kondisi yang bersih, sedangkan untuk karpet dilakukan pencucian setiap 2 bulan sekali. Sepanjang bagian depan tiap shaf dipasang kain putih bersih yang dipergunakan untuk sujud. Hal tersebut sesuai menurut Keputusan Menteri Kesehatan RI Nomor: 288/Menkes/SK/III/2003 tentang "Pedoman Penyehatan Sarana dan Bangunan Umum Masjid, Langgar, dan Surau" bahwa alat sholat harus bersih dan bebas dari kutu busuk dan serangga. Sepanjang barisan (shaf) bagian depan dipasang kain putih yang bersih dengan lebar $30 \mathrm{~cm}$ sebagai tempat sujud.

j. Lantai

Berdasarkan hasil penilaian mengenai keadaan alat sholat di Masjid Ampel tahun 2016 termasuk dalam kategori Baik $(100 \%)$ seperti terlihat pada tabel 3. Lantai di masjid tersebut cukup bersih sebab dilakukan pembersihan setiap harinya untuk lantai bagian dalam, sedangkan untuk lantai bagian luar dibersihkan setiap 2 hari sekali. Kondisi lantai tidak retak dan keramik di masjid tersebut berasal asli dari cina, tidak licin, permukaannya rata dan kedap air sehingga aman untuk beribadah tidak beresiko kecelakaan.Hal tersebut sesuai menurut Rahayu (2013) Lantai yang baik adalah lantai yang dalam kondisi kering dan tidak lembab dan harus kedap air sehingga mudah dibersihkan.

k. Ventilasi

Berdasarkan hasil penilaian mengenai keadaan alat sholat di Masjid Ampel tahun 2016 termasuk dalam kategori Baik $(100 \%)$ seperti terlihat pada tabel 3. Ventilasi alam masjid terbilang baik dan memenuhi persyaratan dimana lubang ventilasi minimal $15 \%$ dari luas lantai, sedangkan untuk ventilasi mekanik pada Masjid Ampel menggunakan kipas angin dengan jumlah yang memadai.Hal tersebut sesuai menurut Sanropie (1989) Luas lubang ventilasi tetap minimal $15 \%$ dari luas lantai ruangan, sedangkan luas lubang ventilasi insidentil (bias dibuka ditutup) minimal $5 \%$ luas lantai.

I. Pencahayaan

Berdasarkan hasil penilaian mengenai keadaan pencahayaan di Masjid Ampel tahun 2016 termasuk dalam kategori Baik (100\%) seperti terlihat pada tabel 3. Kondisi pencahayaan di Masjid Ampel cukup memadai dan tidak menyilaukan pengunjung serta dalam kondisi yang baik yaitu tidak ada yang rusak atau mati. Disiang hari lampu masjid Ampel dimatikan sehingga tidak terjadi pemborosan listrik. Hal tersebut sesuai Menurut Ashari (2014) Pencahayaan alami siang hari dimaksud untuk mendapatkan pencahayaan dalam bangunan pada siang hari dari cahaya alami dan memberikan lingkungan visual yang menyenangkan dan nyaman dengan kualitas cahaya yang mirip dengan kondisi alami di luar bangunan.Disamping itu juga dapat mengurangi atau meniadakan pencahayaan buatan sehingga dapat mengurangi penggunaan energi listrik.

m. Tempat Sandal dan Sepatu

Berdasarkan hasil penilaian mengenai keadaan tempat sandal dan sepatu di Masjid Ampel tahun 2016 termasuk dalam kategori Kurang (10\%) seperti terlihat pada tabel 3. Di Masjid Ampel tidak tersedia tempat sandal dan sepatu yang khusus, sehingga sandal atau sepatu pengunjung tidak tertata. $\mathrm{Hal}$ tersebut tidak sesuai menurut Keputusan Menteri Kesehatan RI Nomor: $\quad$ 288/Menkes/SK/III/2003 tentang "Pedoman Penyehatan Sarana dan Bangunan Umum Masjid, Langgar, danSurau" bahwa Masjid harustersediatempat sandal dansepatu yang khusus.

5. Rekapitulasi Penilaian Hygiene Sanitasi Wisata Religi Sunan Ampel Surabaya.

Dari hasil observasi hygiene sanitasi obyek wisata yang terdiri dari empat variabel yaitu, variabel lingkungan, fasilitas sanitasi, fasilitas penunjang dan sanitasi masjid. Diperoleh hasil observasi yang ditunjukkan pada tabel 4 berikut: 
Tabel 4

Rekapitulasi Penilaian Hygiene Sanitasi Wisata Religi Sunan Ampel Surabaya Tahun 2016

\begin{tabular}{|c|l|c|c|c|c|}
\hline No & \multicolumn{1}{|c|}{ Variabel } & Skor Maks & Skor Obs. & $(\%)$ & Kriteria \\
\hline 1. & Lingkungan & 80 & 58 & 73 & Cukup \\
\hline 2. & Fasilitas Sanitasi & 600 & 465 & 77 & Cukup \\
\hline 3. & Fasilitas Penunjang & 190 & 67 & 35 & Kurang \\
\hline 4. & Sanitasi Masjid & 130 & 109 & 83 & Baik \\
\hline J Jumlah & 1000 & 697 & 69,7 & Cukup \\
\hline
\end{tabular}

umber: Data Primer

BerdasarkanTabel 4 diatas, dapat diketahui bahwa untuk hasil rekapitulasi skor observasi hygiene sanitasi Wisata Religi Sunan Ampel Surabaya Tahun 2016 memperoleh skor 697 (69,7\%) dari skor maksimal 1000 dengan kriteria cukup.

\section{KESIMPULAN}

Penilaian mengenai keadaan fasilitas sanitasi Wisata Religi Sunan Ampel Surabaya termasuk dalam kategori Cukup $(69,7 \%)$.

1. Keadaan lingkungan di Wisata Religi Sunan Ampel Surabaya termasuk dalam kategori Cukup (73\%).

\section{SARAN}

1. Pengelola maupun petugas kebersihan diharapkan untuk selalu memantau dan menjaga kebersihan dilingkungan di area masjid dan makam.

2. Tempat sampah sebaiknya menggunakan tempat sampah yang tidak mudah berkarat dan dilengkapi dengan tutup karena untuk menghindari terbentuknya tempat perindukkan lalat.

3. Pihak pengelola maupun petugas kebersihan diharapkan untuk membuat jadwal pengangkutan sampah ke TPA maksimal 3 hari sekali dan memindahkan lokasi TPS ke lokasi yang tidak banyak dilewati dan didatangi oleh pengunjung sehingga tidak mengganggu estetika dan lalu lintas.

4. Petugas kebersihan diharapkan untuk selalu memantau dan menjaga

\section{DAFTAR PUSTAKA}

Al Amin, Baitullah, 2009. Diktat Drainase Perkotaan.Jurusan Teknik Sipil. Palembang

Ashari. 2014. Kajian Terhadap KenyamananRuangTeori di FakultasTeknikUniversitasNegeri Yogyakarta dtinjau dari Pencahayaan Alami dan Pencahayaan Campuran .http://eprints.uny.ac.id/10014/1/JU RNAL\%20TEKNIK\%20SIPIL.\%20Ash
2. Keadaan fasilitas sanitasi di Wisata Religi Sunan Ampel Surabaya termasuk dalam kategori Cukup (77\%).

3. Keadaan fasilitas penunjang di Wisata Religi Sunan Ampel Surabaya termasuk dalam kategori Kurang (35\%)

4. Sanitasi Masjid di Wisata Religi Sunan Ampel Surabaya termasuk dalam kategori Baik (82\%)

kebersihan toilet, terutama toilet pria agar selalu bersih dan tidak bau.

5. Pengelola obyek wisata diharapkan menambahkan poster himbauan untuk menjaga kebersihan lingkungan beserta keterangan dampak-dampak membuang sampah sembarangan agar pengunjung peduli terhadap kebersihan lingkungan.

6. Sebaiknya menyediakan tempat sandal untuk pengunjung agar sandal pengunjung tertata.

7. Sebaiknya di Wisata Religi Sunan Ampel Surabaya dilengkapi dengan sarana/fasilitas kesehatan minimal tersedianya kotak P3K untuk penanganan pertama pada kecelakaan di lokasi tersebut.
ari\%20Aziz.pdf. Program Studi Teknik Sipil Fakultas Teknik Universitas Negeri Yogyakarta.

Azrul Azwar, 1995, Pengantar IImu Kesehatan Lingkungan, Jakarta : PT. Mutiara Sumber Widya.

Anom (1999) Masjid Kuno di Indonesia.

Departemen Pendidikan dan Kebudayaan. Jakarta: Proyek Pembinaan Peninggalan Sejarah dan Kepurbakalaan Pusat. 
Candra, Budirman, 2007. Pengantar Kesehatan Lingkungan. Jakarta : EGC

Dianika Krisna, 2010. Peranan Pemerintah Kota Surabaya Dalam Mengembangkan Wisata Religi Vol 1 No 1. Malang

Direktorat Jenderal Cipta Karya Dinas PU. 2000. Kriteria Perencanaan

Mustika, Ahsana, 2011. Pengelolaan Wisata Religi (Studi Kasus Makam Sultan Hadiwijaya Untuk Pengembangan Dakwah. No.29. Semarang

Notoatmodjo, Soekidjo, 2010. Metodologi Penelitian Kesehatan. Jakarta: Rineka Cipta

Notoatmodjo, Soekidjo. 2011. Kesehatan Masyarakat IImu dan Seni. Jakata: Rineka Cipta

Permenkes RI No.

416/MENKES/PER/IX/1990.

Syarat-syarat Pengawasan dan Kualitas Air. Jakarta.

Permen-PU No. 06/PRT/M/2007. Pedoman Umum Rencana Tata Bangunan dan Lingkungan. Jakarta

Rahayu. 2013. Hubungan Antara Faktor Lingkungan Fisik Rumah dengan Kejadian Infeksi Saluran Pernapasan (ISPA) pada Balita di Kelurahan Malayang 1 Kota Manado. Fakultas Kesehatan Masyarakat Universitas Sam Ratulangi Manado.

Sanropie, Djasio, dkk. 1989. Pengawasan Penyehatan Lingkungan Permukiman. Jakarta: Departemen.
Kesehatan RI, Pusat PendidikanTenaga Kesehatan.

Santoso Imam, 2015. Inspeksi Sanitasi Tempat-Tempat Umum. Yogyakarta: Gosyen Publishing

Sarudji, Didik. 2006. Kesehatan Lingkungan. Media Ilmu: Sidoarjo.

Suparlan, 2012. Pengantar Pengawasan Hygiene - Sanitasi Tempat-Tempat Umum-Wisata \& UsahaUsaha Untuk Umum. Surabaya: Dua tujuh

SuyonodanBudiman, 2010.IImu Kesehatan Masyarakat Dalam Konteks Kesehatan Lingkungan. Jakarta: EGC

Tobing Imran, 2005. Dampak Sampah Terhadap Kesehatan Lingkungan dan Manusia. http://ebookinga.com/pdf/dampaksampah-terhadap kesehatan lingkungan-dan-

45265579.html. Fakultas Biologi Universitas Nasional Jakarta.

Undang-Undang RI No. 10 Tahun 2009. Tentang Kepariwisataan.

Undang-Undang RI No. 36 Tahun2009. Tentang Kesehatan.

Yoeti, Oeka A, dkk. 2006. Pariwisata Budaya Masalah dan Solusinya. Jakarta: Pradnya Paramita.

Zelly Rinaldi. 2015. Analisa Konstruksi Tahan Gempa Rumah Tradisional Suku Besemah di Kota Pagaralam Sumatera Selatan. Jurusan Arsitektur Universitas Muhamadiyah Jakarta 